\title{
Integrating Local History into Lessons of History Subject in the 2013 Curriculum Revise at Senior High School Level
}

\author{
$1^{\text {st }}$ Rahayu Permana* \\ Social Studies Education Master Program of \\ UNINDRA PGRI \\ Jakarta, Indonesia \\ rahayu.permana@unindra.ac.id
}

\author{
$2^{\text {nd }}$ Febta Pratama \\ Historical Education Studies Program of \\ UNINDRA PGRI \\ Jakarta, Indonesia
}

\begin{abstract}
This paper tried to give a new offer to conduct a process of integration of local history in the history of specialization in the 2013 curriculum. So far local content has been made as a cultural subject, which should also be occupied by sociology and civic education (PPKn). Therefore, this paper wanted to provide an alternative to the teachers that the historical portion of specialization 4 hours weekly meeting. Presumably it was possible to divide into each 2 hour meeting. Of
\end{abstract}

\section{INTRODUCTION}

The curriculum is an important aspect of running the education system. Education is a basic capital for a country to achieve progress. Advanced education is certainly based on the education curriculum of the country that has been well designed. The [1] law on the national education system or UUD Sisdiknas No. 20 the Year 2003 has provided guidance for the government to implement and formulate the education model as expected. The curriculum is an integral part of an education system. The curriculum is basically not something rigid and static. The curriculum is dynamic following the development and dynamics of the times. It is not surprising and reasonable if the curriculum in various countries often experiences changes, changes, and developments from various sides. Included in this curriculum Indonesian country how times changed. The last curriculum is the 2013 curriculum which has also undergone changes, namely the 2013 curriculum revise edition. The curriculum is planned to be implemented in the 2018-2019 school year, there course this changed a bit of a curriculum that has been made, but did not reduce the portion of the real, because essentially the local history was very dependent on the role of Congress Subject Teacher or MGMPs fields of study the History. Therefore, it was they who became the cornerstone of the success of the integration of local history into the history of specialization.

Keywords-Local History, Specialization Historical Subject, Curriculum 2013

are some changes to this curriculum, namely in the core competency section.

Basically, the 2013 curriculum provides fresh air and wind of change for some subjects, especially social science groups. One of these subjects is history subject. Before the 2013 curriculum, history subjects only had 2 hours of meetings a week. The meeting which was only 2 hours long, it made the teachers difficult in developing lessons. However, the presence of the 2013 curriculum made history subjects into this subject in the social science family. Indeed, this curriculum was born as a hope to develop and awaken the values of nationalism that are diminishing among teenagers. Although the other goal is to add hours of history lessons that are considered inadequate. Although this curriculum is considered by some education experts as a premature curriculum, it seems that it is forced to enforce it. However, inevitably this curriculum has been running and all stakeholders are obliged to support developing this curriculum to make it better. The learning material that is meant is the learning material of local history. For this reason, the paper will try to discuss the opportunity to integrate local 
historical material into the history of specialization material at the high school level using the 2013 curriculum.

\section{METHOD}

This research uses descriptive qualitative research methods, with a case study approach. Because this study wants to uncover facts, the process of how to debate about local history in history subjects in the 2013 curriculum. The determination of the research subject is carried out purposively with certain considerations. Data collection techniques carried out by interview, observation, and document analysis. Sugiyono (2014: 319) said that there were several types of interviews namely, structured interviews, semi structured interviews, and unstructured interviews. The semi structured interview aims to find more open problems. In collecting this data, researchers used interview techniques, the interview used was a semistructured interview. The semi-structured interview was chosen because the researcher wanted to know the problem being studied more openly, where the research subjects interviewed were invited to express their opinions and ideas. Included in this semistructured interview is an in-depth interview [2].

The 2013 Curriculum for Senior High School/ MA and History Subjects

Conceptually the curriculum is an educational response to the people's needs and the nation in building the young generation. Pedagogically the curriculum is seen as an educational design that provides opportunities for students to develop their potential in a pleasant learning environment. Juridical, the curriculum is a public policy based on the philosophical basis of the nation's juridical decision funds in the field of education. The juridical foundation of the curriculum is the Pancasila and the 1945 constitution. UUD No. 20 the Year 2003 concerning the national education system. Government regulation No. 19 the Year 2015 and the national minister of education regulation No. 23 the Year 2006 concerning graduate competency standards and regulation of the Minister of National Education No. 22 The year 2006 concerning content standards.
Building a curriculum is certainly not only with a juridical foundation but also with a philosophical foundation. Philosophically, the development of education, especially the curriculum, must be rooted in national culture, the future of the nation and the future of the nation. Theoretically, the curriculum is concerned with problems with value standards that will later give birth to Graduates Competency Standards or SKL. According to the curriculum, the law is a set of plans and arrangements regarding the objectives, contents, and learning materials and the methods used as guidelines for the implementation of learning activities to achieve the educational objectives of the guidelines [1] [3] Government Regulation No. 19 the Year 2005.

The juridical foundation of the 2013 curriculum is the 1945 Constitution of the Republic of Indonesia or UUD. UUD No. 20 the Year 2003 concerning the national education system. UUD No. 17 the Year 2005 concerning the national long term development plan, and all provisions that are respected by the national medium term development plan. Government regulation No. 19 the Year 2005 concerning national education standards as amended by government regulation No. 32 the Year 2013 concerning changes to government regulation No. 19 the Year 2005 concerning national education standards [3].

In accordance with the beginning, every subject in the 2013 curriculum must have subject names according to their fields of study, so in this curriculum, the subjects of the social sciences also have their own names. Specifically for history subjects, in this curriculum, there are two historical subjects, namely mandatory Indonesian history subjects and Specialization Indonesian history subjects. In mandatory Indonesian history subjects, each face to face is charged 2 hours a week. Meanwhile, the history of specialization for $\mathrm{X}$ grade is charged 3 hours of meetings and XI and XII's grades are charged 4 hours per week. This shows that the history of specialization is preferred in the 2013 curriculum, especially historical subjects.

History is the science of the origin and development of society which has important meaning as a past experience, while history 
education is a process of internalizing the values of knowledge and historical skills from a series of events designed and arranged in such a way as to influence and support the learning process student [4]. Historical subjects of specialization appear rationally because a) history is a light of truth, a witness of time and a teacher of life (Historia Magistra Vitae); b) history as a leader of the human soul to be strong and resistant to fiber terror chaos in life; c) history has hygienic influence on our soul because it frees from mere trustworthiness; d) history has a strategic meaning in the formation of dignified character and national civilization and in the formation of Indonesian people who have a sense of nationality and love for the country (Permendiknas 22 Year 2016 concerning Standards Content) [5].

Historical subjects, both compulsory and special the learning objectives can be categorized or grouped into 8 objectives, namely: 1) developing an understanding of self, society, and nation; 2) developing a sense of nationality, love for the country, and appreciation for results and national achievement; 3 ) build awareness of students about the importance of the concept of time and space in historical thinking; 4) develop the ability to think history, historical skills, and insight into historical issues, and apply these abilities, skills, and insights in today's life; 5) develop behaviors based on values and morals that reflect the character of self, society and nation; 6) instill attitudes oriented to the present and the future; 7) understand and be able to handle controversial issues to examine the problems that occur in the community; 8) developing international understanding in examining phenomena a classic and global. Of the eight learning objectives the fourth point is the core of historical learning goals [6].

In terms of subject matter, specialization subject groups especially history, the subject matter is not much different from mandatory Indonesian history, except that this material emphasizes the fourth point namely historical insight and historical issues. The material talks more about the basic principles of history and world history. Although there is general historical material in Indonesia, details are not explained. Seeing the content of the material, of course, this material is good for general, with a meeting time of 4 hours for XI and XII grades and 3 hours meeting for $X$ grade. However, the 2013 curriculum, especially subjects of history, both mandatory subjects and specialization subjects, has not shown its locality. With the many portions of historical subjects in the 2013 curriculum, locality and character values can be inserted from local events. This means that both mandatory and specialization history subjects have not embraced the portion of local history in subject matter, especially in the subjects of specialization history.

\section{Local History}

Local history is very synonymous with spatial concepts, namely the concept of territory. Where today there are many historians are too admiring colonial buildings as part of local history. This is why we sometimes dichotomize between regions without a clear view. Borrowing the sentence Karl Jaspers, according to Karl Jaspers without a perspective on the future our view of the past has been 'finished' and 'complete' and that is false. Jaspers said In Hariyono said we will easily lose perspective, which is called "prognostic historical thinking", something that will give an explanation of future life orientation [7]. According to Soedjatmoko in Hariyono [7], "our view of history, has a decisive influence on confrontation the Indonesian nation in the future and thus, for the fate of our nation and country". To maintain the dimension of Indonesian's in the future, where diverse regions and cultures of Indonesia, require more detailed explanation and understanding as well as diverse knitted materials, local history has a strategic meaning and function.

Some historians have tried to make a series of meanings from local history including the historian Taufik Abdullah. In the classic book edited by Taufik Abdullah in Hariyono [7], it is stated that what is meant by local history is the "history of a "place", a "locality", whose limits are determined by "the agreement" submitted by the historical writer". This is not much different from what was stated by Carol Kammens in Hariyono [7] which states that "local history is the study of past events, or people or groups, in a given geographic area". The focus of the local history can be the place itself, the people who have held events in a particular location. From 
this definition, we can take a view that is between local history and regional history.

This condition proves that history that occurs in a particular location is not something isolated from wider events. Michael Lewis [8] in Hariyono [7], said "We are fortune the methods of environmental history, literally, grounded and oriented toward local reflecting larger case studies cultural trends or natural situations (culture and nature, of course, used advisedly we have no excuse other than time and our lack of knowledge for incorporating local history into our environmental history course". The interconnectedness of events in a particular local area and elsewhere was also colored by various episodes of historical events that preceded it. The impact is that there is no single history. Historical events tend to be "multi-history".

Human experience at the local level that produces history or events tends not to be written but is told through stories that sometimes touch the natural cosmic realm and are usually peppered with myths. Soedjatmoko in Hariyono said that "the experience of mankind is not recognized as history, but it is obtained and frozen in stories that explain human relations with the cosmic order of nature, and in stories that illustrate the ways in which humans should face exams- exam in this mortal world" [7]. Local history, in general, is often colored by myths (clouded in myth) often encouraging historians to dissolve in their opinions when conducting research. That is, researchers dissolved with the assumption of local communities where the event was perceived so far. The cultural values and presuppositions of local people are more used as references than available theoretical and methodological references. Therefore an understanding of methodology and theory that is relevant to the topic under study becomes indispensable in local historical research [7]. The existence of history as a logical science by applying research patterns according to procedures, so that local history can truly be understood by the researcher. By understanding the local history above, it allows historical research and writing not only to be descriptive but also to be carried out analytically and reflectively. Local history research can also be a part of the "self-awareness" movement as well as a means of developing learning capacity for researchers and readers. For researchers, it is necessary to read the relevant sources on the topic of interest [7]. For this reason, local history research is indeed necessary from the topic selection, there is evidence of its initial foothold so that it is easier in conducting the next stage of research.

Syamsudin in Hariyono said that when selecting the topic, the steps and methods are determined [7] which are needed in the process of data collection. It can be started by reading the relevant literature further than observing the site or monument, looking for documents that are relevant or supportive to the possibility of conducting interviews (oral history) or exploring oral traditions [9] that are relevant to the topic being studied. After a variety of data has been collected, then validity and reliability are verified There are a lot of events in this archipelago or Indonesia whose scope can be included in the local history category. Even in just one province, there are many events that might be more local. Even in a smaller scope, between events and events that are of a local nature are not always the same and tend to be opposite and contradictory. An example is the war Paregreg which occurs between West Majapahit (Mojokerto) and East Majapahit (Blambangan now Banyuwangi). The community is different in responding to these events within the locality of the local community, this is the task of the historian in introducing and learning history to the community, especially students at school. In this case, the History Teachers' Consultation (MGMP) has an important role in providing an understanding of local history, which in the 2013 curriculum has not been so apparent. This is what draws attention to how to integrate local history in specialization history subjects In the era of autonomy there are now many benefits of local history and regional history, according to Hariyono [7], stating that there are at least two benefits of regional history in the framework of development in the era of regional autonomy, namely 1) regional history as a means to explore and find build regional identity and personality (character building); 2) regional history as a means to build social solidarity which is 
indispensble in regional development; 3) regional history as a vehicle for social referrals.

\section{RESULTS AND DISCUSSION}

\section{Integration of Local History into Specialization History Subjects}

Taufik Abdullah in Hariayono [7] said the historical style of Indonesian society is categorized into three, namely (1) history is a part of the national heritage that is maintained but eventually becomes the past wrapped in cultural desires and assumptions. The history of this type is always commemorated as national holidays; (2) history created (invented remembered history) which is a statement of political and cultural desires in the form of narration. Many historical events have become embodied memories subordinated by embedded history. Both of these features play an important role in social dynamics. In the process of nation formation it cannot be well described without taking into account these two modes of historical writing; (3) history that is recovered (recovered history), which is to depart from the desire to find a lost past event. Even though historians also need to understand and remind the weaknesses of historical "historical" and "made" historical values, the main task is to find scientific truth. Therefore there is often historical debate related to "factual accuracy" (historical truth/certainty) and the style of remembered history subjectivity and invented history.

The legal basis for the integration of local history in the history of specialization is the [1] Law on National Education System or UUD Sisdiknas No. 20 the Year 2003 explains that local content is a study material to shape students' understanding of the potential of their residential areas. National Education Minister No. 22 Year 2006 concerning standard content 2a states that local content is a subject that must be given to all educational spaces [9]. In the 2013 curriculum in senior high school, especially in the Social Sciences Cluster, there are specialization history subjects that have a large portion of time around 4 hours a week. From the 4 hours of the meeting, it is possible to integrate local history into learning material. To facilitate how to integrate it, of course, the most authorized are the respective schools and especially the teachers of history studies through MGMP. Currently, the MGMP is less than optimal in applying the learning process. There is a regulation that the high school level is currently the parent organization is no longer under the district but is directly sheltered in the provincial government. This is certainly the task of the MGMP History of each province to formulate how to integrate local history in the history of specialization. Local history is important as a source of learning. Haryono said that the use of local history at any level of education would enable students to study history to resonate with the aspects of Eigenwelt they had (Sartono Kartodirdjo in Soedarsono, in Hariyono [7]). Local history exposure can bridge students in understanding various historical events in the surrounding community with historical events in other regions. Through local history studies, students are stimulated to be able to see the process of national integration as a historical event. Local historical sites also have tourist attractions. The tourists usually want to see the uniqueness that does not exist in the area of origin and has never been met. For tourists, a historic place with local history is a unique attraction that becomes a tourist attraction. This can at least be revealed from someone's motivation in traveling. The existence of historical sites is very vulnerable to crime; stolen, or deliberately sold by local residents to collectors of ancient relics. We certainly don't want one future generation, regardless of its historical roots because of the destruction and destruction of historical sites. Before it's too late, it's time for the government to be helped by the community, tracking the history of important sites, both major and minor, in the form of writing. Indeed there is a slanted impression about the writing of narratives on local historical sites. Some people consider it a futile job; because there is already a full version written by historians from other countries (Netherlands) [10].

With local history taught in class and outside the classroom, that means students know firsthand how the personal and biographical life of the perpetrator of history. They can ask about the life side of the perpetrator of history. With a good question and answer technique, students can recognize and emulate the souls of the 
history actor's leadership wisely and wisely. How they sacrifice anything for the sake of upholding independence is what students need to appreciate in learning local history. Learning local history provides more active opportunities for students to explore information independently of planned goals. Through the information of the caretaker, the civil service, and cultural officers the students become more familiar with the social character of historical actors. How historical actors fight for noble ideological values and in accordance with the context of togetherness in life at that time will inspire students to practice the same things in today's life. Learning local history also provides a lot of information about what culture has developed in its territory in the past [10]. As Doudi in Hariyono stated [7], that the teaching of local history is able to break through the boundary between the sociological psychological world when students directly recognize and appreciate the environment of their communities where they are part of the environmental community. Bishop [11] said merging two subjects in one curriculum will facilitate the achievement of a material. The integration of two curricula, namely local history and national history will make it easier for students to explore their potential and innovate with material that already exists in the curriculum structure.

Through local history teaching, students are invited to get closer to the real situation of their immediate environment. Next, bring students directly to know and experience the community environment, where they are part of it. It is not wrong to say that the teaching of local history is able to break the boundary between the "school world" and "the real world" outside of school. From teaching local history students will get many examples and experiences from various stages of the development of their community environment, including the present situation. They will also be more motivated to develop specific skills such as observation, asking questions or conducting interviews, selecting sources, finding facts, etc. During this time the loud one is heard is a boring history lesson, full of memorization of facts, so it is not interesting [10]. Currently learning history is still wrapped with national history which lacks local value. Meanwhile, local history seems to be sinking by itself, due to an unfinished debate among historians. Meanwhile, class learning requires local history and culture to be developed. Considering that at this time many students do not know the history and culture of their area, therefore, it is important to create a standard local historical narrative to facilitate students in understanding history learning [12].

The opportunity for integration is actually in the local content for the 2013 curriculum. Government Regulation No 32 Year 2013 article 77N concerning Amendments to Government Regulation No 19 Year 2005 concerning National Education Standards, which states that: (1) local content for each education unit contains contents and the learning process of local potential and uniqueness; (2) the content was developed and implemented in each education unit of the Minister of Education and Culture 81A Annex II concerning the Local Content Guidelines which explained that one of the scopes of local content was to preserve and develop regional culture. But this paper tries to give a new offer that the integration of local history is not only through local content but can be through the history of specialization in which the portion of the hour is 4 hours. Okay, therefore, to broaden the understanding of local history, it is important for the 2 hours of study in the history of specialization to be devoted to local history of each region and to the curriculum given to MGMP teachers in the field of study, given the local history of each area varies from region to region with other regions. Then, the formula was given to the respective MGMP then transferred to the teachers to be taught to each school according to the portion of 2 lessons for XI grade and XII grade and one lesson for $X$ grade. The table of a division of integration of local history in the history of specialization is as follows. 
Table 1. Integrating Local History into Specialization Historical History Subject

\begin{tabular}{lll}
\hline & \multicolumn{2}{c}{ Historical Subject } \\
\hline Grade & \multicolumn{1}{c}{ Specialization Historical } & \multicolumn{1}{c}{ Local History } \\
\hline$X$ & 2 hours meeting & 1 hour meeting (material according to the region) \\
\hline Sum & 3 hours meeting weekly & \\
\hline XI & 2 hours meeting & 2 hours meeting (material according to the region) \\
\hline Sum & 4 hours meeting weekly & \\
\hline XII & 2 hours meeting & 2 hours meeting (material according to the region) \\
\hline Sum & 3 hours meeting weekly & \\
\hline
\end{tabular}

The table still refers to the time-sharing table in the 2013 curriculum imposed by the government. Table 1 is only an overview of the lesson hours between local history and the history of specialization. Each of them has two hours of meeting to explain the material. What is meant by integration here is that local history occupies 2 hours of its own meeting from the history of specialization without having to add new subjects and take subjects of local content which are basically also needed by other subjects? This means that two hours of specialization history subjects are devoted to local history subjects. Without having to change these historical subjects, that means one subject is two subjects, namely local history lessons and history of specialization. Considering the 2013 curriculum provides a substantial portion of time for specialization history subjects.

As for the local history material that will be taught is adjusted to the locality of each region. For example, in West Java, the history of West Java consists of local history in each district, for example, if the local history is an administrative area. Of course, the local history of the Garut and Ciamis regions will be different from Cirebon. This should not be a differentiator, but this diversity of local history should make us love our homeland more because we have many tribes and diverse cultures. Here the MGMP in the field of study and history teacher takes the most roles. In addition to providing national historical material, of course, local history needs to be given, will students be able to understand and respect leaders and appreciate the events that have occurred in their neighborhoods.

Another example is that local leaders Sunan Kali Jaga who spread propaganda in Java are certainly not relevant if taught in Sumatra, specifically Aceh. So to compensate for this, it needs to be raised in the local history of Aceh's Ulama figures whose influence is also great, such as Hamzah Fansuri, and Abdul Rauf AsSinkili. Because both of them have different characteristics and locations in spreading Da'wah. This is what local history will teach in the history of specialization material. The methods and teaching are given directly to each teacher, either by tourism or by inquiry.

\section{CONCLUSIONS}

At the end of this paper, it is once again necessary to convey that the integration of local history into the history of specialization is very possible, given the history of specialization with a very large portion of hours of meeting, local history in the author's opinion can be integrated by incorporating local history in the history of specialization by taking portions two hours of lessons from the history of specialization. Taking or dividing the hours is very possible and without changing the name of the subject. It's just that at this party, all stakeholders must work together to remember the local history of each region differently. So it needs uniformity at the provincial level considering that the senior high school (SMA) and Islamic senior high school-Madrasah Aliyah (MA) now have authority in the Provincial Government. Although when in the field everything is returned to school and MGMP in the field of study to raise which local history will be displayed or made into the material. Regarding the learning method, it is not necessarily a scientific method, but the method of tourism and inquiry is much more interesting and challenges students to be 
directly involved and feel how local events in the area where they live can occur.

\section{ACKNOWLEDGMENTS}

Acknowledgments the authors say to several parties so that the author can finish this paper.

\section{REFERENCES}

[1] Law on the national education system (No. 20/2003).

[2] Agustinova, D. E. (2014). Diktat Pegangan Kuliah Metodelogi Penelitian Kualitatif Jilid 1 (Revisi). Yogyakarta: FIS UNY.

[3] Regulation No. 19/2005 Concerning the National Standard Education

[4] Sukmadinata, Nana Syaodih. (2011). Pengembangan Kurikulum Teori dan Praktek. Bandung: Remaja Rosdakarya.

[5] Agung, Leo. (2015). Sejarah Kurikulum Sekolah Menengah di Indonesia: Sejak Kemerdekaan hingga Reformasi. Yogyakarta: Ombak.

[6] Regulation of the Minister of National Education in 2006 about Number 22
Standard Content For the units of Primary and Secondary Education.

[7] Hariyono. (2017). Sejarah Lokal: Mengenal Yang Dekat, Memperluas Wawasan. Jurnal Sejarah dan Budaya, 11(2), pp. 160-166.

[8] Lewis, M. (2004). Reflections: This Class Will Write a Book: An Experiment in Enviromental History Pedagogy. In Journal of Environmental History, 7, pp. 604-605.

[9] Vansina, J. (2014). Tradisi Lisan Sebagai Sejarah. Jogyakarta: Ombak.

[10] Umamah, N. (2016). Integrasi Sejarah Lokal dalam Kurikulum Sejarah SMA Peluang dan Kendala (Studi kasus Pengembangan Kurikulum SMA di Kabupaten Jember). Jakarta: Program Studi Ilmu Sejarah Fakultas Ilmu Pengetahuan dan Budaya.

[11] Bishop, Penny A dan Kathleen Brinegar. (2011). Student Learning and Engagement in the Context of Curriculum Intergation Middle Grades Research Journal, 6(4), pp. 207.

[12] Wibowo, Agus. (2010). Pentingnya Narasi Sejarah Lokal, dalam Harian Umum SOLOPOS Edisi Senin, 18 Januari 2010. 